\title{
OVERVIEW OF THE MARKET OF MINCED MEAT PRODUCTS AND WAYS TO IMPROVE THE TECHNOLOGY OF SEMI- FINISHED PRODUCTS OF A HIGH DEGREE OF READINESS
}

\author{
Kristina Nechepurenko', Olena Zolotukhina ${ }^{2}$, Galina Horbenko ${ }^{3}$, Bogdana Starostenko ${ }^{4}$, \\ Irina Panikarova ${ }^{5}$, Tatyana Karpova ${ }^{6}$ \\ ${ }^{1}$ Department of Food Technology, Hotel and Restaurant Business, Kharkiv College of Trade and Economics, Kyiv National University of \\ Trade and Economics, Kharkiv, Ukraine \\ hechepyrenko@gmail.com \\ ORCID: https://orcid.org/0000-0002-1815-2542 \\ ${ }^{2}$ Department of Food Technology, Hotel and Restaurant Business, Kharkiv College of Trade and Economics, Kyiv National University of \\ Trade and Economics, Kharkiv, Ukraine \\ zolotukhinaelena2212@gmail.com \\ ORCID: https://orcid.org/0000-0003-0792-0558 \\ ${ }^{3}$ Department of Food Technology, Hotel and Restaurant Business, Kharkiv College of Trade and Economics, Kyiv National University of \\ Trade and Economics, Kharkiv, Ukraine \\ Klyntik07@gmail.com \\ ${ }^{4}$ Department of Chemistry, Microbiology and Food Hygiene, Kharkiv State University of Food Technology and Trade, Kharkiv, Ukraine \\ panikarovadana@gmail.com \\ ${ }^{5}$ Cyclic Commission of Social and Humanitarian Disciplines, Kamenskoye State Power Engineering College, Kamenskoye, Ukraine \\ panikakrovairina60@gmail.com \\ ${ }^{6}$ Department of heat treatment of metals named after K. F. Starodubov, National Metallurgical Academy of Ukraine, Dnipro, Ukraine \\ vprytomanov@gmail.com \\ ORCID: https://orcid.org/0000-0003-3999-0980
}

ARTICLE INFO

\section{Article history:}

Received date 26.03 .2021

Accepted date 27.04.2021

Published date 30.04 .2021

Section:

Food Science

DO I

$10.21303 / 2313-8416.2021 .001806$

KEYWORDS

chopped semi-finished meat products stabilization of emulsion systems vegetable oils

increasing the thermal stability of meat products

\section{ABSTRACT}

In view of the difficult economic and epidemiological situation in the country, the question arises of an unbalanced diet of the population and an overabundance of low-quality food ingredients and additives on the consumption market. The studies represent the experience of processing products of the meat industry, in particular chopped semi-finished products of a high degree of readiness from beef, pork and various compositions of the latter. Since with an excessive amount of fat, the daily diet of the Ukrainian population suffers greatly due to the lack of high-quality, easily digestible animal protein. It is the excess of fats with easily digestible carbohydrates that leads to the rejuvenation of diseases such as obesity, varicose veins, heart attacks and strokes.

A review of the market for raw meat is made, the main methods of increasing the nutritional value of chopped semi-finished products of a high degree of readiness from meat are outlined. The advantages of using vegetable oils with partial replacement of animal fats, ways of improving the introduction of liquid vegetable oils through the use of structured stabilization systems based on compositions of a polysaccharide nature, namely sodium alginate, carraginans, which in turn are bound by calcium residues, enriching the composition of products are also easily digestible, bound by calcium.

The object of research: the technology of production of minced semi-finished products of a high degree of readiness from meat, a system for stabilization of minced semi-finished products from meat.

Investigated problem: obtaining a stable dispersion system inside chopped semi-finished products of a high degree of readiness from meat by introducing stabilizing ingredients into the technology.

Main scientific results: the optimal concentrations of replacing animal fats with vegetable ones have been revealed. It is shown that the introduction of vegetable fats as a part of structured emulsion systems as part of chopped semi-finished products of a high degree of readiness from meat helps to reduce technological losses during heat treatment from 60 to $5 \%$.

The area of practical use of the research results: enterprises of the restaurant industry and the food industry, specializing in the manufacture of minced semi-finished products of a high degree of readiness from meat.

An innovative technological product: a technology for the production of chopped semi-finished products of a high degree of readiness from meat using structured emulsion systems as part of structured emulsion systems, which makes it possible to stabilize the technological process of introducing flowing vegetable oils by emulsifying and structuring.

Scope of application of the innovative technological product: the production of chopped semi-finished products of a high degree of readiness from meat is possible at factories for processing raw meat, in the field of restaurant industry, private small industries that specialize in frozen semi-finished products of a high degree of readiness. 


\section{Introduction}

\section{1. The object of research}

The object of research is the ways of improving the introduction of liquid vegetable oils by using structured stabilization systems in the composition of chopped semi-finished products of a high degree of readiness from meat.

\section{2. Problem description}

As is known from literary sources, products of slaughter of farm animals and poultry are multicomponent structurally complex systems. Depending on their composition and properties, they are used for the production of food products, feed and technical products, and medicines [1].

The nutritional value of raw meat is determined from the quantitative ratio of moisture, protein, fat, the content of essential amino acids, polyunsaturated fatty acids, B vitamins, micro- and macroelements, as well as the organoleptic characteristics of meat [2].

It is very important to establish a representative relationship between the numerical values of the parameters and the quality indicators of products at all stages of the technological process [3], which allows to constantly monitor the production process. Whereas the smell and taste of chopped semi-finished meat products of a high degree of readiness depend on the amount and composition of extractive substances, the presence of volatile components and those transformations in their composition that occur during the technological process or heat treatment.

Glutathione, carnosine, anserine, glutamic acid, threonine, sulfur-containing amino acids, nucleotide decomposition products, creatine influence the formation of the taste and aroma characteristics of raw meat. Also creatinine, carbohydrates, fats and a wide range of volatile components (sulfur-containing, nitrogen-containing, carbonyl compounds, fatty acids, keto acids, products of melanoid solution reactions) [4].

For the technological use of chopped semi-finished products of a high degree of readiness from meat, one of the most important indicators is consistency (tenderness and juiciness). The latter, in turn, depends on the amount of connective tissue, intramuscular fat, the size of muscle bundles and the diameter of muscle fibers, according to the state of muscle proteins - the degree of their hydration, the interaction of myosin and actin, the level of destruction. The tenderness of meat is influenced not only by the total content of connective tissue, but also by the ratio of collagen and elastin in it, the degree of polymerization of the main substance - mucopolysaccharides [5].

In addition, under the concept of functional technology or commodity properties of raw meat, a set of properties characterizing the nutritional and biological value, organoleptic, structural and mechanical, functional and technological, sanitary and hygienic and other signs of finely prepared semi-finished products from soft meat are used.

Since meat raw materials are multicomponent and heterogeneous in composition and properties, it is necessary to consider the specifics of the main meat tissues. Muscle, adipose and connective tissues, their quantitative ratio, qualitative composition and processing conditions are of more technological importance [6].

The quantitative ratio of tissues in meat is approximately: muscle tissue $-50 \ldots 70 \%$, adipose tissue $-3 \ldots 20 \%$, bone tissue $-15 \ldots 22 \%$, connective tissue $-9 . .14 \%$ [7] .

It is known that the proteins in different foods are not equal. Of the 20 amino acids, 8 are essential, unlike others, they are not synthesized in the body, they can only be obtained from food. For this reason, $30 \%$ of the daily protein diet of a person should be complete proteins, the source of which is meat, containing all essential amino acids; the annual human need for complete protein is $20 \mathrm{~kg}$ [8].

The authors of [9] indicated that all proteins of muscle tissue to a greater or lesser extent participate in the formation of the structure of minced meat, while exhibiting properties characteristic of high molecular weight compounds. So as a result of the "protein-protein" interaction is the formation of jelly, the "protein-water" interaction - swelling and dissolution of proteins, binding of moisture. Interaction in the "protein-fat" system leads to grease-clay and fat binding, and in the "protein-fat-water" system it promotes the formation of emulsions and foam, and proteins in this case exhibit surface-active properties. All these processes occur simultaneously during the preparation of minced meat, which is confirmed by the formation of a certain consistency [10]. 
However, the formation of a mixture occurs as a result of the interaction of protein macromolecules with each other. The consequence of this is the formation of a three-dimensional spatial mesh capable of retaining moisture and other components of the minced meat in the interpolymer space [9]. During heat treatment, due to thermocoagulation of proteins, an elastic frame is formed, which determines the strength of the structure of the finished product, which can be considered as a thermotropic gel. Its stability mainly depends on the drag-forming ability of the dissolved part of myofibrillar proteins [11]. However, the aforementioned jellies are not stable as water-binding agents and, when exposed to high heat treatment temperatures, they lose moisture, reducing the product yield.

Thus, it is known from the literature review that the drag-forming ability of proteins depends on the concentration and type of protein, $\mathrm{pH}$ of the medium, temperature, particle size, as well as the content of salts and other substances, as well as the structure, strength of the protein-forming protein.

Thus, when choosing sources of protein substances, or proteins for the production of minced semi-finished products of a high degree of readiness from meat, various aspects must be taken into account. In this case, not only technological properties, such as texture and color, should be taken into account, but also the quality of the product, the impact on health and the price.

However, it should be noted that the weak point of meat proteins is that they can't contain all the bound water without losing the strength of their structure [12]. This leads to the loss of water, fat, juiciness and, therefore, adversely affects the cost and organoleptic characteristics of the finished product.

Water, being the main component in food, can be in a wide variety of forms of connection. In this case, the binding energy is of decisive importance [13]. The connection of moisture is carried out by intermolecular forces (van der Waals forces), which is due to three effects: orientational (electrostatic). The first predominates in substances with polar molecules; induction (deformation), which prevails in matter with quasi-elastic dipoles. And the third is dispersive, when a molecule is polarized in the field of neighboring molecules [14].

The relative share of these effects for different substances is different, so, according to [15], Van der Waals forces of interaction take place at a distance of up to $0.1 \ldots 1.2$ microns, i.e., much larger than the molecules themselves.

A reliable method for assessing the bond forms of water and classifying its forms is to use for this purpose the value of the bond energy - the free energy of the dehydration process, as is customary in physicochemical thermodynamics: chemically bound, adsorbed-bound, osmotically bound, capillary-bound [14].

Thus, it is the amount and form of bond in the raw meat that determines the organoleptic characteristics of the finished product, such as juiciness and consistency.

According to the formula for a balanced diet, taking into account the energy and biological aspects [16], the daily consumption of an adult should be $80 \ldots 100 \mathrm{~g}$ (including $20 \ldots 25 \mathrm{~g}$ of vegetable) fats. In turn, the content of essential polyunsaturated fatty acids should be $2 \ldots 6 \mathrm{~g}, 35 \mathrm{~g}$ of oleic acid and $20 \mathrm{~g}$ of saturated fatty acids. In addition, the ratio between the amount of polyunsaturated and saturated fatty acids should be $0.3 \ldots 0.35 \%$.

The above data are generalized, because different varieties of meat raw materials differ in composition and have different calories, fat and protein content.

If to consider the territory of Ukraine as a whole, then beef, as a raw material, possessing a number of advantages, has a significant drawback - a significant part of the carcass meat can't be used to prepare natural fried culinary products that are in high demand among consumers.

Thus, meat is a biologically valuable food raw material, has great potential for use in various technologies of meat products.

Based on the analysis of the works of scientific authors [9], a review of the market for modern minced semi-finished products of a high degree of readiness from meat showed that most of the products are represented by semi-finished products of a high degree of readiness, mainly produced by small firms [7] and is probably determined by the local significance of developments.

Chopped meat raw materials, or minced meat, can be considered as an emulsion of fat in water, while salt-soluble proteins are stabilizers of the emulsion. It should be noted that the emul- 
sion of minced meat can be stable only in the presence of emulsifying substances, which, being adsorbed on the surface of fat droplets, prevent them from sticking together [16]. In meat systems, such emulsifiers with revealed surface activity are salt-soluble proteins of muscle tissue, as well as natural constituents of fats - lecithin, cholesterol, monoglycerides.

Thus, the main problem in the production of chopped semi-finished products of a high degree of readiness from meat is that the production of gels, emulsification, improvement of consistency, structuring, stickiness and viscosity depend on the use of structured stabilization systems. The latter ensure the quality of the product, for example, improving the structure, increasing the juiciness, water and fat-binding properties of minced meat.

\section{3. Suggested solution to the problem}

The above-mentioned problems of minced semi-finished products of a high degree of readiness from meat can be solved using the structural and mechanical properties of minced meat systems, which significantly depend on the components that are introduced into the minced meat according to the recipe, for example, the use of structured stabilization systems.

The aim of research is to develop a technology for the production of chopped semi-finished products of a high degree of readiness from meat as part of structured emulsion systems.

\section{Materials and Methods}

One of the most important characteristics that make it possible to assess the consistency of crushed semi-finished meat products of a high degree of readiness is the value of the ultimate shear stress. Compared to changes in the values of other rheological properties (plastic effective viscosity, stickiness, bulk characteristics, etc.), the ultimate shear stress is most sensitive to changes in technological and mechanical factors. Therefore, a similar indicator is used to assess the high degree of readiness crushed meat semi-finished products in the manufacturing process.

The ultimate shear stress was determined by the formula:

$$
\theta=k \frac{m}{h^{2}}+k^{\prime}
$$

where $q$ - ultimate shear stress, $\mathrm{Pa} ; k$ - indenter constant, which depends on its apex angle $(k=0.687 \mathrm{ctg} 2 \mathrm{a}) ; m-$ mass of the indenter and the rod of the device acting on the investigated product (after removing the friction and resistance of the indenter spring), $\mathrm{kg} ; h$-depth of immersion of the indenter into the product, $\mathrm{m} ; k^{\prime}$ - coefficient taking into account the friction forces:

$$
k^{\prime}=\frac{\operatorname{tg}\left(\frac{\alpha}{2}\right) \cdot \sqrt{9 \operatorname{tg} \cdot\left(\frac{\alpha}{2}\right)+4}}{3 \operatorname{tg}^{2}\left(\frac{\alpha}{2}\right)+1}
$$

The structure resistance was characterized by the ultimate shear stress of the undestroyed structure, which was investigated on semi-automatic penetrometers Labor, Ukraine [17]

\section{1. Experimental procedures}

If to proceed from the temperature dependence of the consistency parameter, that is, from the values of viscosity at a shear rate of $\gamma=1 \mathrm{~s}^{-1}$ (Fig. 1), then it is possible to estimate the average values of the activation energy $E_{a}$ of solutions in the studied temperature ranges. They grow with increasing concentration and are equal to $26 \ldots 36 \mathrm{~kJ} / \mathrm{mol}$ for alginate solutions (Table 1).

These values of the activation energy $E_{a}$ for aqueous solutions of alginate are $1.5 \ldots 2$ times greater than in water, and leads to an increase in the forces of attraction between molecules and their behavior as thickeners.

These large activation energies are associated with the strength of bonds and the large number of these hydrophilic hydrogen bonds in macromolecules of structured stabilization systems. 


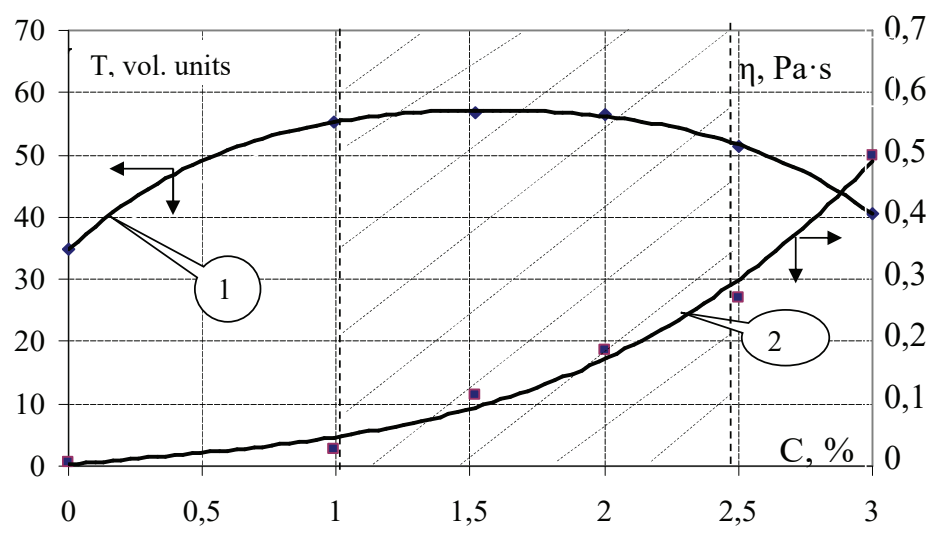

Fig. 1 Rheogram of the model of structured stabilization systems at temperatures: $1-21 \pm 1{ }^{\circ} \mathrm{C}$;

$$
2-67 \pm 2{ }^{\circ} \mathrm{C}
$$

Table 1

Estimates of the activation energy $E_{a}$ for structured stabilization systems from their concentration C, \%

\begin{tabular}{|c|c|}
\hline Concentration of structured stabilization systems C, \% & $E_{a}, \mathrm{~kJ} / \mathrm{mol}$ \\
\hline 0.5 & 27.0 \\
\hline 1 & 26.4 \\
\hline 1.5 & 30.5 \\
\hline 2 & 32.8 \\
\hline 2.5 & 36.2 \\
\hline
\end{tabular}

From the results of studies of the activation energy of the phase inversion point and the rheogram, it can be seen that the characteristics of structured stabilization systems, as a medium for oil dispersion, will differ significantly depending on the concentrations of polysaccharides. It is possible to assume that the ability of the emulsion to separate will determine the possibility of intermolecular interaction of polysaccharides and will emulsify with an increase in $E_{a}$ values, while the ability of the system to emulsify with an increase in the $E_{a}$ state will be relatively stable.

Fig. 2 shows the data of the dependence of the phase inversion point on the concentration of polysaccharides. This can also be interpreted as a dependence on the viscosity of the system. It is confirmed that within the concentration range of systems $0 . .3 .5 \%$ with an increase in the concentration of structured stabilization systems, the viscosity increases. Parallel studies of the inversion point and the corresponding viscosity values are presented.

Shear stress, $\mathrm{Pa}$

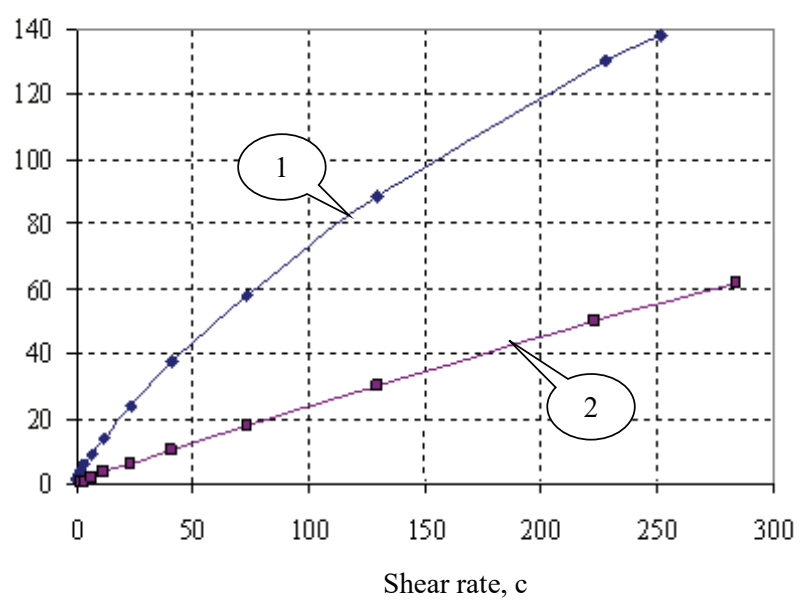

Fig. 2. Characteristics of the parameters of the formation of the emulsion: 1 - point of phase inversion of the emulsion (T); 2 - viscosity of the solution of structured stabilization systems 
Analyzing the experimental data obtained, it should be noted that the use of structured stabilization systems is characterized by an extreme dependence of the phase inversion point on the concentration when it is used as a dispersion medium for oil emulsification. From Fig. 2, it can be understood that for an increase in the concentration of structured stabilization systems to $1.2 \%$ and higher, the emulsification limit is reached, while the value of the inversion points is $55 . .58$ vol. unit. A further increase in concentration is accompanied by a decrease in the inversion point. So, the value of the inversion point for a solution with a content of $2.0 \%$ of structured stabilization systems is $51 \ldots .50$ vol. unit, which is 1.2 times less than the maximum value.

\section{Results}

Summarizing the data from Table 1 and Fig. 2, it can be concluded that the extreme values of the point of inversion and decrease in emulsifying ability is observed against the background of an increase in viscosity. Probably, starting from a concentration of $2.0 \%$ for structured stabilization systems, a lack of free moisture begins to appear in the system, and it complicates emulsification. Thus, the use of structured stabilization systems in the technology of crushed semi-finished products of a high degree of readiness from meat is promising precisely in concentrations of $1.0 \ldots 2.0 \%$.

For maximum realization of the properties of structured stabilization systems as an emulsifier, obtaining an emulsion must be carried out at a concentration in the system of $1.0 \ldots .5 \%$; while the concentration of the solution in $1.5 \ldots 2.0 \%$ corresponds to the maximum fat content, which is $63.5 \pm 5 \%$. Obviously, the emulsifying ability is not affected by temperature as a viscosity factor of the system within the temperature range of $20 \ldots 70{ }^{\circ} \mathrm{C}$. For this value, the concentration range for using structured stabilization systems $1.0 \ldots 2.5 \%$, this value is relatively constant.

According to the innovative concept, the structural and logical scheme for obtaining high-readiness crushed semi-finished products from meat using structured stabilization systems is shown in Fig. 3.

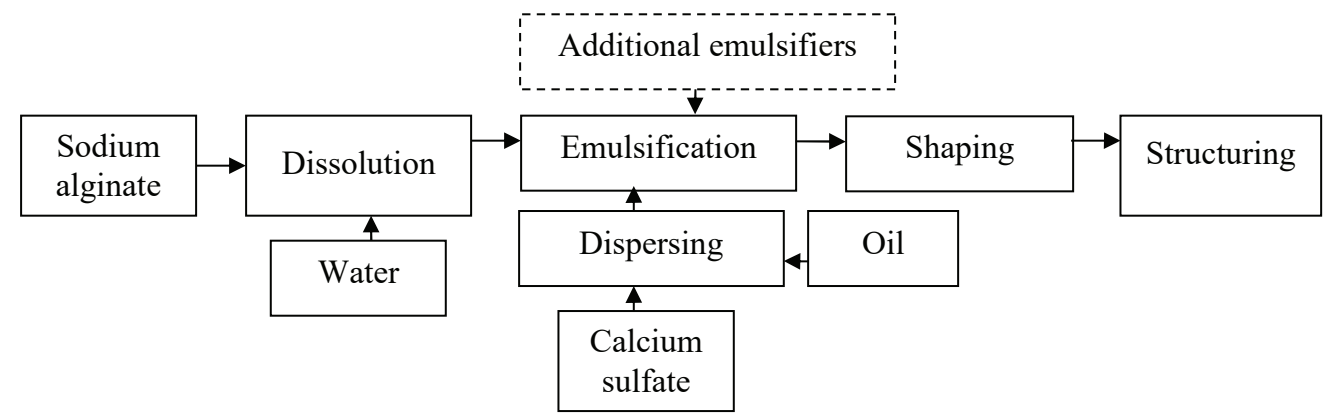

Fig. 3. Structural and logical diagram of obtaining structured stabilization systems

From the analysis of the data in Fig. 3, one can see the main technological stages that predict the logic of research of the technological process of production in the direction of improving the quality of chopped semi-finished products of a high degree of readiness from meat. It can also be noted that intensive scientific developments have been carried out throughout the world for decades, resulting in a huge flow of information in fundamental and periodicals. Research is conducted in many different directions, each of which has its own advantages and disadvantages.

\section{Discussion}

As a result, scientists [14] had an outstanding change in the ultimate shear stress, plastic and effective viscosity depending on the moisture content in the crushed semi-finished products of high degree of readiness from meat caused by an increase in the amount of water associated with protein macromolecules. This is confirmed by similar studies by scientists [18], which showed that the size of muscle fibers increases with increasing moisture content due to osmotic diffusion of moisture. Whereas the process of thickening of the water layers causes a decrease in the strength of the structure, it is significantly inhibited by the reverse process - swelling of muscle fibers, an increase in their surface and the binding of water, which contributes to an increase in strength. The total effect 
of these processes results in a relatively small decrease in strength [16] for crushed semi-finished products of a high degree of readiness from meat.

The research results are explained by the structural-logical scheme of the technological process, namely by the determination of the parameters of the process, obtaining a stable dispersion system inside chopped semi-finished products of a high degree of readiness from meat by introducing stabilizing ingredients into the technology.

The results solve the problem of the stability of emulsion systems and the stability of dispersed phases in the production of a stable dispersion system inside chopped semi-finished products of a high degree of readiness from meat by introducing stabilizing ingredients into the technology. The research data are based on the temperature dependences of the activation energy of stabilizing ingredients, different concentrations of ingredients and readings of the viscosity of solutions to obtain a stable dispersion system inside minced semi-finished products of a high degree of readiness from meat.

In the course of research, the problem of fluidity of emulsion systems, fractionation of free moisture during heat treatment was identified, for its solution into chopped semi-finished products of a high degree of readiness from meat to obtain a stable dispersion system inside, it was decided to introduce stabilizing ingredients into the technology, namely, compositions determined experimentally carrageenan and calcium alginate.

Limitations in research can be considered the maximum concentration of proteins and the minimum amount of animal fats required in the daily diet of a person.

Further research is planned towards the development of healthy eating, vegetarianism, Vedic and religious, lean food and the development of related technologies.

\section{Conclusions}

An analysis of the modern market for split ends with a high degree of readiness from meat revealed development at a rapid pace and in many directions. This is facilitated by the development and implementation of a large number of new technologies by domestic and foreign scientists.

It is known that the meat industry is one of the largest sectors of the food industry and is designed to provide the country's population with food products, which are the main source of proteins, but animal fats are enriched with excess cholesterol, which leads to a number of diseases.

The main technological stages that predict the logic of research of the technological process of production in the direction of improving the quality of chopped semi-finished products of a high degree of readiness from meat have been investigated.

It has been determined that the use of structured stabilization systems in the technology of crushed semi-finished products of a high degree of readiness from meat is promising precisely in concentrations of $1.0 \ldots 2.0 \%$.

It is confirmed that within the concentration range of systems $0 \ldots 3.5 \%$ with an increase in the concentration of structured stabilization systems, the viscosity increases, thus stabilizing the crushed semi-finished meat products.

From the results of studies of the activation energy of the phase inversion point and rheogram, it can be seen that the characteristics of structured stabilization systems, as a medium for oil dispersion, will differ significantly depending on a certain concentration of polysaccharides, because emulsions of plant stabilization systems in crushed semi-finished meat products of a high degree of readiness can be stable only in the presence of additional raw materials, of a polysaccharide nature, which, being adsorbed on the surface of fat droplets, prevent them from sticking together.

\section{References}

[1] Kochetkova, A. A., Tuzhilkin, V. I. (2003). Funktsionalnye pischevye produkty: nekotorye tekhnologicheskie podrobnosti v obschem voprose. Pischevaia promyshlennost, 5, 8-13.

[2] Samsonov, M. A. (2001). Kontseptsiia sbalansirovannogo pitaniia i ee znachenie v izuchenii mekhanizmov lechebnogo deistviiapischi. Voprosy pitaniia, 5, 3-9.

[3] Vasilevskaia, L. S., Okhnianskaia, L. G. (2002). Fiziologicheskie osnovy problemy pitaniia. Voprosy pitaniia, 2, $42-45$.

[4] Spirichevm, V. B., Shatniuk, L. N., Pozdniakovskii, V. M. (2013). Obogaschenie pischevykh produktov mikronutrientami: nauchnye podkhody i prakticheskie resheniia. Pischevaia promyshlennost, 3, 10-17. 
[5] Assadpour, E., Dima, C., Jafari, S. M. (2020). Fundamentals of food nanotechnology. Handbook of Food Nanotechnology, 1-35. doi: http://doi.org/10.1016/b978-0-12-815866-1.00001-7

[6] Shenderov, B. A., Trukhanov, A. I. (2002). Produkty funktsionalnogo pitaniia: sovremennoe sostoianie i perspektivy ikh ispolzovaniia $\mathrm{v}$ vosstanovitelnoi meditsine. Vestnik vosstanovitelnoi meditsiny, 1, 38-42.

[7] Gorbatov, A. V., Machikhin, Iu. A., Maksimov, A. P. et. al. (1990). Reometriia pischevogo syria i produktov (spravochnik). Moscow: Agropromizdat, 270.

[8] De Cindio, B., Baldino, N., Gabriele, D., Lupi, F. R. (2016). Rheological Properties of Food Materials. Encyclopedia of Food and Health, 610-617. doi: http://doi.org/10.1016/b978-0-12-384947-2.00592-4

[9] Samsonov, M. A. (2011). Kontseptsiia sbalansirovannogo pitaniia i ee znachenie v izuchenii mekhanizmov lechebnogo deistviia pischi. Voprosy pitaniia, 5, 3-9.

[10] Vasilevskaia, L. S. (2002). Fiziologicheskie osnovy problemy pitaniia. Voprosy pitaniia, 2, 42-45.

[11] Dudenko, N. V., Pavlotskaia, L. F., Evlash, V. V. (2007). Pischevaia, biologicheskaia tsennost i bezopasnost syria i produktov ee pererabotki. Kyiv: INKOS, 287.

[12] Smoliar, V. I. (2000). Fiziolohiia ta hihiiena kharchuvannia. Kyiv: Zdorovia, 180.

[13] Tutelian, V. A. (2001). Biologicheski aktivnye dobavki v profilakticheskom i lechebnom pitanii. Evoliutsiia vzgliadov i podkhodov. Biologicheski aktivnye dobavki k pische i problemy zdorovia semi. Krasnoiarsk, 3-5.

[14] Pivovarov, P. P., Grinchenko, O. O., Mikhailov, V. M., Ivanov, S. V., Kovalenko, A. A., Pivovarov, C. P. et. al. (2011). Innovative technologies of the new generation food products manufacturing for mass consumption. Available at: http://kdpu-nt.gov.ua/uk/ content/innovaciyni-tehnologiyi-vyrobnyctva-harchovoyi-produkciyi-novogo-pokolinnya-masovogo

[15] Lu, R., Abbott, J. A. (2004). Force/deformation techniques for measuring texture. Texture in Food, 109-145. doi: http://doi.org/ 10.1533/978185538362.2.109

[16] Liu, Y.-X., Cao, M.-J., Liu, G.-M. (2019). Texture analyzers for food quality evaluation. Evaluation Technologies for Food Quality, 441-463. doi: http://doi.org/10.1016/b978-0-12-814217-2.00017-2

[17] Postnov, H. M., Chekanov, M. A., Dub, V. V., Chervonyi, V. M. (2006). PAT. No. 16116 UA. Prystrii dlia vymiriuvannia liniinykh peremishchen. MPK G 01 B 9/00. No. U200602096. declareted: 27.02.06; published: 17.07.06, Bul. No. 7.

[18] Pasichnyi, V. M., Yastreba, Yu. A. (2010). Doslidzhennia strukturno-mekhanichnykh vlastyvostei heliv alhinativ dlia vyrobnytstva strukturovanykh produktiv na osnovi hrybnoi syrovyny. Obladnannia ta tekhnolohii kharchovykh vyrobnytstv, 24, $256-261$. 